\title{
Strategi bisnis, leverage keuangan dan kinerja perusahaan
}

\author{
Krismiaji \\ Akademi Akuntansi YKPN, Yogyakarta, Indonesia \\ e-mail:xmiaji@gmail.com
}

\section{A R T I K E L I N F O}

Article history:

Available online

Keywords:

leverage, strategy, performance

\section{A B S T R A C T}

This paper is an empirical research investigating the impact of business strategy toward causality relationship between corporate leverage and its financial performance. Sample used in this study are 645 manufacture company listed in Indonesia Stock Exchange (IDX) during period of 2010 - 2014. Company's performance is measured by Market to Book Value ratio, leverage is measured by dividing total debt to total assets, and competitive strategy is measured by dummy variable, where 1 is for company adopted product differentiation strategy and 0 is for those adopted cost leadership strategy. This research found negative impact of leverage toward financial performance and the impact is more severe for company adopted product differentiation strategy. The result of this research is expected to help explaining why the previous studies investigated direct relationship between leverage and performance tend to be not consistent and contradictive.

\begin{abstract}
A B S T R A K
Paper ini mendiskusikan hasil riset empiris yang menginvestigasi pengaruh strategi bisnis terhadap hubungan kausalitas antara leverage keuangan dan kinerja perusahaan. Riset ini menggunakan sampel sebanyak 645 observasi perusahaan manufaktur yang terdaftar di bursa efek Indonesia (BEI) tahun 2010 sampai dengan tahun 2014. Kinerja perusahaan diukur menggunakan rasio nilai pasar terhadap nilai buku (market-to-book ratio), leverage keuangan diukur dengan membagi utang dengan total asset, dan strategi bersaing diukur dengan menggunakan variabel dummy, yaitu bernilai 1 untuk perusahaan yang mengadopsi strategi diferensiasi produk, dan 0 untuk perusahaan yang mengadopsi strategi kepemimpinan biaya. Riset ini menemukan adanya hubungan negatif antara leverage dan kinerja perusahaan dan hubungan ini lebih negatif pada perusahaan yang mengadopsi strategi diferensiasi produk. Hasil riset ini dapat membantu memperjelas mengapa riset terdahulu yang meneliti hubungan langsung antara leverage dan kinerja cenderung tidak konsisten dan bertentangan.
\end{abstract}

\section{Pendahuluan}

Paper ini mendiskusikan riset empiris yang menginvestigasi pengaruh strategi bisnis terhadap hubungan antara leverage keuangan dan kinerja perusahaan. Penelitian ini dimotivasi oleh hasil penelitian tentang hubungan antara leverage keuangan dan kinerja perusahaan yang cenderung tidak konsisten (mixed) bahkan seringkali hasilnya saling berlawanan. Sebagian penelitian terdahulu menghasilkan temuan bahwa leverage keuangan berpengaruh positif terhadap kinerja perusahaan (Weill 2003; Berger dan Patti 2006; Akhtar et al. 2012), sebagian menghasilkan temuan bahwa leverage keuangan berpengaruh negatif terhadap kinerja perusahaan (Ahmad et al. 2015; Javed et al. 2015; Shaheen 2014; Rajkumar 2014; Evgeny 2015; Mule dan Mukras 2015; Enekwe et al. 2014; Ali 2014), dan sebagian lagi menghasilkan temuan bahwa leverage keuangan tidak berpengaruh terhadap kinerja perusahaan (Tahir et al. 2014)

Selain motivasi di atas, penelitian ini juga dimotivasi oleh pertentangan beberapa teori terdahulu. Modigliani dan Miller (1958) menyatakan bahwa struktur modal irrelevan dalam penentuan nilai perusahaan karena nilai perusahaan ditentukan oleh aset riilnya, bukan oleh sekuritas yang dikeluarkan oleh sebuah perusahaan. Model ini memakai asumsi dasar pasar modal yang sempurna sehingga beberapa pakar menganggap bahwa teori ini tidak dapat dipakai dalam pembuatan keputusan riil. Meskipun demikian, asumsi ideal tersebut justru memberikan peluang untuk manganalisis dan memasukkan pengaruh variabel lain yang lebih riil terhadap 
nilai perusahaan. Oleh karena itu, Jensen dan Meckling (1976) menentang proposisi ini dengan menyatakan bahwa besaran leverage dalam struktur modal sebuah perusahaan mempengaruhi pilihan manajer terhadap aktivitas operasi dan aktivitas tersebut pada gilirannya mempengaruhi kinerja perusahaan. Jermias (2008) dan Rahimi (2016) menganggap bahwa hasil yang tidak konsisten tersebut sebagian disebabkan oleh pendekatan yang digunakan. Penelitian terdahulu hanya menggunakan efek langsung leverage keuangan terhadap kinerja. Jermias (2008) dan Rahimi (2016) menganggap bahwa pengaruh leverage keuangan terhadap kinerja mungkin dipengaruhi oleh strategi yang digunakan oleh perusahaan. Megginson (1997) menyatakan bahwa pola struktur modal di setiap Negara berbeda, misalnya Negara maju seperti US, UK, Jerman dan Kanada memiliki debt ratio yang lebih rendah dibandingkan debt ratio di Jepang, Prancis, Italia dan Negara Eropa lainnya. Hal ini dibuktikan oleh hasil penelitian yang dilakukan oleh Weill (2003) yang memperoleh hasil yang berbeda pada riset di Italia, Prancis, dan Jerman, yaitu hubungan yang negatif di Italia dan hubungan yang positif di Prancis dan Jerman. Berdasarkan paparan di atas, ada celah untuk melakukan penelitian lanjutan untuk menguji pengaruh variabel tersebut dengan obyek penelitian perusahaan yang terdaftar di bursa efek Indonesia. Penelitian ini memasukkan variabel strategi bersaing untuk menginvestigasi pengaruh leverage keuangan terhadap kinerja.

Tujuan penelitian ini adalah untuk menginvestigasi pengaruh strategi bisnis terhadap hubungan antara leverage keuangan dan kinerja perusahaan. Dengan mendasarkan pada teori agensi, peneliti memprediksi bahwa pengaruh leverage keuangan terhadap kinerja lebih negatif bagi perusahaan yang menerapkan strategi diferensiasi produk dibandingkan perusahaan yang menerapkan strategi cost leaders. Penelitian ini memberikan kontribusi bagi literatur tentang hubungan antara leverage keuangan dan kinerja perusahaan dan memiliki implikasi kebijakan bagi para praktisi. Temuan penelitian ini menunjukkan bahwa substitusi sebuah struktur modal dengan struktur modal yang berbeda berpengaruh terhadap kinerja, namun pengaruh ini dimoderasi oleh strategi bersaing yang dipilih oleh perusahaan. Temuan ini tidak konsisten dengan teori ekuitas akuntansi dan proposisi irrelevant (Modigliani dan Miller 1958). Meskipun demikian temuan ini mendukung ide bahwa keputusan pendanaan dan pilihan strategi mempengaruhi kinerja perusahaan (Harris 1994; Jensen dan Meckling 1976). Temuan ini juga berpotensi untuk membantu praktisi untuk menyadari bahwa keuntungan pajak yang diperoleh dari pendanaan utang dan kemampuan perjanjian utang untuk mengendalikan perilaku oportunistik manajer dapat secara efektif meningkatkan kinerja perusahaan yang mengadopsi strategi diferensiasi produk.

Bagian berikutnya paper ini diorganisasi sebagai berikut. Bagian kedua mengkaji teori dan penelitian terdahulu untuk merumuskan hipotesis penelitian. Bagian ketiga menjabarkan metode penelitian dan Bagian ke empat merinci analisis data dan hasil uji statistis. Bagian akhir memaparkan temuan penelitian dan keterbatasan penelitian, termasuk implikasi dan peluang penelitian lanjutan.

\section{Tinjauan Pustaka dan Perumusan Hipotesis}

Penelitian ini menggunakan teori agensi yang menyatakan bahwa dalam hubungan agensi, manajer/agen tidak selalu bertindak untuk kepentingan pemegang saham atau prinsipal (Jensen dan Meckling 1976). Oleh karena itu, perlu ada mekanisme untuk meminimumkan tindakan manajer atau mendorong agar manajer mau bertindak untuk kepentingan pemegang saham yaitu dengan menambah utang. Penambahan utang berakibat perubahan struktur utang baik jangka pendek maupun jangka panjang dan struktur utang ini akan mempengaruhi pilihan manajer terhadap aktivitas operasi dan aktivitas tersebut pada gilirannya mempengaruhi kinerja perusahaan (Jensen dan Meckling 1976).

Meskipun terdapat banyak penelitian yang bertujuan untuk menjelaskan hubungan antara leverage keuangan dan kinerja, literatur yang ada sekarang masih belum mampu menjelaskan apakah keberadaan utang merupakan hal yang baik atau buruk. Argumen dan temuan empiris menunjukkan arah yang tidak seragam, ada yang mengatakan baik namun banyak juga yang mengatakan buruk. Sebagian peneliti menyatakan bahwa leverage memiliki pengaruh buruk terhadap kinerja. Sebagai contoh, Jensen dan Meckling (1976) menunjukkan bahwa ada biaya agensi (biaya monitoring dan bonding) yang terkait dengan pendanaan utang karena para kreditur perlu memproteksi kepetingannya dalam sebuah perusahaan. Myers (1977) menunjukkan bahwa pendanaan utang menyebabkan pemegang saham mengalami under-invest (investasi terlalu rendah) karena sebagian penerimaan hasil investasi mengalir ke kreditur, sehingga menyebabkan kinerja perusahaan menjadi sub-optimal. Simerly dan Li (2000) menyatakan bahwa kenaikan utang meningkatkan pengaruh kreditur melalui debt covenants yang dapat membatasi pilihan manajer dan mengurangi kemampuan manajer untuk mengelola perusahaan secara efektif. Karena kreditur cenderung menekankan pada tujuan jangka pendek guna memuaskan tujuan utama mereka yaitu menerima pelunasan pokok pinjaman dan bunga sebagaimana tercantum dalam kontrak, maka peningkatan pengaruh kreditur dapat membahayakan keselamatan perusahaan dalam jangka panjang (Jensen 1986). 
Balakrishnan dan Fox (1993) menyatakan bahwa kenaikan pendanaan utang akan meningkatkan risk aversion para manajer dan menurunkan keinginan untuk melakukan investasi pada proyek yang lebih berisiko meskipun proyek tersebut lebih menguntungkan, dan beberapa penelitian juga menemukan adanya hubungan negatif antara leverage dan kinerja (misalnya, Gleason et al. 2000; Balakrishnan dan Fox 1993). Peneliti lain menemukan hal yang berlawanan. Mereka menyatakan bahwa leverage keuangan memiliki pengaruh positif terhadap kinerja perusahaan. Jensen (1986) berpendapat bahwa debt covenants dapat mengendalikan perilaku oprtunistik para manajer dengan cara mengurangi arus kas yang tersedia untuk pengeluaran diskresi. Jensen (1986) menganggap bahwa dengan mengeluarkan surat utang, para manajer terikat pada janji untuk melunasi utang di masa mendatang dengan menggunakan arus kas mendatang. Alasan untuk melakukan hal tersebut adalah bahwa ketidak mampuan untuk memenuhi perjanjian utang berakibat pada financial distress dan kebangkrutan dan berakhir pada penggantian manajer (Jensen 1989).

Lubatkin dan Chatterjee (1994) menyatakan bahwa bunga adalah tax deductible dalam mendukung argumentasi bahwa utang memperbaiki kinerja perusahaan karena sebagian biaya modal (cost of capital) berpindah dari pemegang saham ke pemerintah. Harris

dan Raviv (1991) berpendapat bahwa tingkat utang yang lebih tinggi menyelaraskan kepentingan pemegang saham dan manajer. Para peneliti tersebut menyatakan bahwa dengan menaikkan utang, sebuah perusahaan mengintensifkan pengaruh para kreditur, sehingga dapat membatasi kemampuan para manajer untuk membuat keputusan yang diyakini oleh para kreditur berdampak negatif terhadap perusahaan. Perjanjian (bonding agreement) antara sebuah perusahaan dengan para kreditur dapat mendisiplinkan para manajer untuk menjalankan perusahaan secara lebih efisien (Jensen 1986). Selain itu, beberapa penelitian empiris juga menemukan adanya hubungan positif antara leverage keuangan dan kinerja perusahaan (Spence 1985; Ghosh et al. 2000; Weill 2003; Berger dan Patti 2006; Javed et al. 2015).

Dari uraian di atas dapat diringkas bahwa penelitian terdahulu tidak berhasil memberikan bukti yang konsisten, hubungan sistematis antara leverage keuangan dan kinerja perusahaan (Harris dan Raviv 1991). Hasil penelitian tidak hanya tidak konsisten, namun juga kontradiktif. Oleh karena itu, beberapa peneliti seperti O'Brien (2003) dan Barton dan Gordon (1988) menggunakan pendekatan yang lebih integratif dengan mempertimbangkan variabel-variabel kontinjen yang secara teoritis dapat dijustifikasi ketika melakukan penelitian tentang hubungan leverage-kinerja perusahaan. Penelitian ini menginvestigasi pengaruh moderasi strategi bisnis terhadap hubungan antara leverage dan kinerja. Penelitian ini menunjukkan bahwa utang memiliki kos dan manfaat dan bahwa faktor-faktor pemoderasi akan mempengaruhi besaran relatif keduanya.

\section{Strategi Bisnis, Leverage Keuangan, dan Kinerja}

Inkonsistensi temuan penelitian terdahulu tentang hubungan antara leverage keuangan dan kinerja perusahaan disebabkan antara lain oleh pendekatan yang digunakan oleh peneliti (Jermias 2008). Sebagian besar peneliti menggunakan pendekatan universal, yang menguji pengaruh langsung leverage keuangan terhadap kinerja. O'Brien (2003) menengarai bahwa penelitian terdahulu mengabaikan pengaruh strategi bisnis perusahaan dan menganggap bahwa kondisi ini bisa menjelaskan mengapa hasil penelitian terdahulu tidak konsisten.

Porter (1985) mengembangkan sebuah rerangka yang memetakan cara perusahaan memiliki strategi bisnis yang tepat agar dapat berkompetisi secara efektif. Porter (1985) berpendapat bahwa sebuah perusahaan harus memilih antara berkompetisi sebagai produsen berbiaya paling rendah dalam industri masing-masing (cost leadership strategy) atau berkompetisi dengan cara menghasilkan produk yang unik dalam konteks kualitas, karakteristik fisik, atau layanan khusus (product differentiation strategy). Porter (1996) menekankan bahwa esensi strategi bisnis sebuah perusahaan adalah kemampuannya untuk secara sengaja memilih serangkaian aktivitas yang akan menghasilkan nilai yang unik bagi para pelanggannya. Klasifikasi strategi bisnis yang dibuat oleh Porter (1985), baik cost leadership maupun product differentiation dianggap oleh banyak pakar secara konsep valid dan secara akademik well-accepted (Dess dan Davis 1984; Hambrick 1983). Penelitian terdahulu yang menggunakan klasifikasi seperti ini antara lain Chenhall dan Langfield-Smith (1998), Govindarajan dan Fisher (1990) dan Govindarajan (1988).

Beberapa penelitian terdahulu juga menjelaskan mengapa hubungan antara leverage dan kinerja tergantung pada pilihan strategi yang dilakukan oleh sebuah perusahaan. Perusahaan yang menggunakan strategi cost leadership akan memperoleh manfaat dari penggunaan leverage berupa kenaikan efisiensi manajerial karena monitoring yang dilakukan oleh para kreditur (Jordan et al. 1998). Menurut Jensen (1986), monitoring yang dilakukan oleh para kreditur juga membatasi perilaku oportunistik para manajer dengan mengurangi sumberdaya yang tersedia untuk pengeluaran diskresi. Oleh karena itu, Jensen (1986) berpendapat bahwa fungsi kontrol utang lebih penting bagi perusahaan yang ingin meningkatkan efisiensi. Porter (1985) berpendapat bahwa perusahaan 
yang mengadopsi trategi cost leadership perlu mengendalikan kos secara ketat, melakukan pemangkasan banyak biaya yang terkait dengan kegiatan inovasi atau pemasaran, dan menurunkan harga jual produk.

Di sisi lain, Miller (1987) menganggap bahwa perusahaan yang mengadopsi strategi product differentiation cenderung melakukan investasi besar-besarn dalam aktivitas riset dan pengembangan produk, guna meningkatkan kemampuan inovatif dan menaikkan kemampuan untuk berada di level inovasi yang setara dengan para pesaingnya. Kendala kenaikan utang dan persyaratan untuk memenuhi perjanjian utang akan cenderung mengurangi kreativitas dan inovasi para manajer, padahal kreativitas dan inovasi ini penting untuk menjaga keuntungan kompetitif bagi perusahaan yang mengadopsi strategi product differentiation (Balakrishnan dan Fox 1993; Simerly dan Li 2000). Sementara itu, Biggadike (1979) menganggap bahwa perusahaan yang mengadopsi strategi product differentiation menghadapi ketidakpastian yang tinggi, karena penekanan pada inovasi yang sangat besar membuat perusahaan terlibat pada aktivitas yang lebih berisiko dan menghasilkan produk yang belum banyak dikenal oleh pasar. Hal ini berakibat pada kesulitan dan keengganan perusahaan untuk menggunakan utang dalam jumlah yang lebih besar (O'Brien 2003; Baginski dan Wahlen 2003).

Dua penelitian empiris yang dilakukan oleh Barton dan Gordon (1988) dan O'Brien (2003) menemukan bahwa strategi bisnis dan leverage keuangan berinteraksi secara signifikan untuk mempengaruhi kinerja perusahaan. Dengan demikian ada beberapa bukti empiris yang mendukung argumen bahwa pilihan strategi bisnis oleh sebuah perusahaan dapat mempengaruhi hubungan antara leverage keuangan dan kinerja. Sebagaimana dipaparkan sebelumnya bahwa ada manfaat dan pengorbanan dari utang dan pertanyaan empirisnya adalah manakah yang lebih dominan, manfaatnya atau pengorbannya? Hasil penelitian awal menunjukkan bahwa hubungan antara leverage dan kinerja adalah negative (Jermias 2008). Oleh karena itu, peneliti mengharapkan bahwa hubungan antara leverage dan kinerja akan negatif dan hubungan ini akan menjadi lebih negatif untuk perusahaan yang mengadopsi strategi product differentiation dibanding perusahaan yang mengadopsi strategi cost leadership. Secara spesifik, hipotesis dirumuskan sebagai berikut:

H1. Pengaruh leverage terhadap kinerja bervariasi diantara strategi yang berbeda, yaitu hubungan tersebut akan menjadi lebih negatif untuk perusahaan yang mengadopsi strategi product differentiation dibanding perusahaan yang mengadopsi strategi cost leadership.

\section{Metoda Penelitian}

Penelitian ini menggunakan model regresi moderasian untuk menguji hipotesis sebagai berikut:

$\mathrm{PFM}_{i \mathrm{t}}=\alpha+\beta_{1} \mathrm{STR}_{\mathrm{it}}+\beta_{2} \mathrm{LEV}_{\mathrm{it}}+\beta_{3} \mathrm{STR}_{\mathrm{it}} * \mathrm{LEV}_{\mathrm{it}}+\beta_{4} \mathrm{SIZE}_{\mathrm{it}}+\beta_{5} \mathrm{IO}_{\mathrm{it}}+\beta_{6} \mathrm{DIV}_{\mathrm{it}}+\varepsilon_{\mathrm{it}}$

$\mathrm{PFM}_{\mathrm{it}}=\alpha+\beta_{1} \mathrm{STR}_{\mathrm{it}}+\beta_{2} \mathrm{LEV}_{\mathrm{it}}+\beta_{3} \mathrm{SIZE}_{\mathrm{it}}+\beta_{4} \mathrm{IO}_{\mathrm{it}}+\beta_{5} \mathrm{DIV}_{\mathrm{it}}+\varepsilon_{\mathrm{it}}$

\section{Keterangan:}

$\mathrm{PFM}_{\mathrm{it}}=$ Kinerja perusahaan i pada tahun $\mathrm{t}$, dihitung dengan rasio nilai pasar dengan nilai buku aset;

$\mathrm{STR}_{\mathrm{it}}=$ strategi yang diadopsi oleh perusahaan yang diberi nilai 1 untuk perusahaan dengan strategi cost leadership dan 0 untuk product differentiation;

$\mathrm{LEV}_{\mathrm{it}}=$ Leverage keuangan perusahaan i pada tahun $\mathrm{t}$, dihitung dengan rasio total utang dengan nilai buku aset;

$\mathrm{SIZE}_{i \mathrm{t}}=$ ukuran perusahaan, diukur dengan jumlah aset perusahaan pada tahun $\mathrm{t}$ dan merupakan variabel kontrol;

$\mathrm{IO}_{\mathrm{it}} \quad=$ Kepemilikan institusional, diukur dengan rasio jumlah lembar saham yang dimiliki oleh pemegang saham institusi terhadap jumlah lembar saham biasa yang beredar; dan

DIV $_{\text {it }}=$ Dividend pay out, diukur dengan jumlah dividen yang diumumkan untuk saham biasa dibagi dengan laba sebelum pos luar biasa.

Hipotesis $\mathrm{H}_{1}$ terbukti atau dikonfirmasi jika koefisien estimasian pada variabel interaksi STR*LEV positif dan signifikan.

\section{Pemilihan Sampel}

Sampel yang digunakan dalam penelitian ini adalah perusahaan manufaktur yang terdaftar di bursa efek Indonesia (BEI) tahun 2010 sampai dengan tahun 2014. Industri manufaktur dipilih sebagai sampel penelitian karena perusahaan yang tergabung dalam industri manufaktur cenderung menerapkan strategi yang berbeda untuk berkompetisi secara efektif dan dengan menggunakan satu industri sebagai sampel meminimumkan persoalan sample heterogeneity (Moores dan Yuen 2001; Ginsberg dan Venkatraman 1985). Data diperoleh dari berbagai sumber, yaitu database BEI, ICMD, dan dari laporan tahunan perusahaan. 


\section{Pengukuran Variabel}

\section{Kinerja}

Simons (2000) menyatakan bahwa ukuran kinerja seharusnya dirancang untuk membantu para manajer memantau implementasi strategi bisnis dan untuk menunjukkan efektifitas ukuran tersebut dalam membantu perusahaan mencapai tujuannya. Dua ukuran kinerja yang biasanya digunakan untuk menilai kinerja perusahaan adalah ukuran berbasis akuntansi dan ukuran berbasis pasar. Ukuran kinerja berbasis akuntansi seperti return on equity (ROE) dan return on investment (ROI) cenderung lebih dapat dikendalikan oleh para manajer dan lebih mudah dimanipulasi dibanding ukuran berbasis pasar (Jermias 2008). Meskipun demikian, ukuran berbasis akuntansi cenderung underestimate kinerja perusahaan sehingga berakibat pada dilakukannya investasi besar periode sekarang (seperti inovator) dengan harapan memperoleh manfaat di masa mendatang. Sebaliknya, ukuran kinerja berbasis pasar, seperti nilai pasar ekuitas cenderung lebih obyektif dan tidak dapat dikendalikan oleh manajer (Merchant dan Van der Stede 2007). Oleh karena itu, penelitian ini menggunakan rasio nilai pasar dan nilai buku (market-to-book ratio) untuk mengukur kinerja perusahaan. Keuntungan utama proksi kinerja ini adalah kinerja rasio tersebut memperhitungkan harapan kinerja perusahaan di masa mendatang (O'Brien 2003). Market-to-book ratio dihitung dengan membagi nilai pasar perusahaan (harga saham akhir periode dikalikan jumlah lembar saham yang beredar) dengan nilai buku jumlah aset.

\section{Strategi bisnis}

Perusahaan diklasifikasi ke dalam rerangka klasifikasi Porter (1985). Beberapa peneliti menggunakan tipologi Porter untuk mengklasifikasi strategi bisnis (misalnya, O'Brien 2003; Robinson dan McDougall 2001; Chenhall dan Langfield-Smith 1998) dan klasifikasi tersebut diyakini oleh bayak pakar dapat diterima secara akademis dan konsisten secara internal (Dess dan Davis 1984; Hambrick 1983). Perusahaan diklasifikasi ke dalam product differentiators atau cost leaders menggunakan analisis klaster hirarkis, yang secara obyektif mengklasifikasi variabel berdasarkan persamaan atau perbedaannya. Untuk mengklaster perusahaan, dalam penelitian ini digunakan pendekatan yang pernah dilakukan oleh Singh dan Agarwal (2002) dan Jermias (2008), yang menggunakan dua golongan variabel, yaitu: efisiensi utilitas aset (diukur menggunakan rasio total penjualan terhadap total aset), dan kapabilitas harga premium (diukur dengan rasio laba kotor terhadap total penjualan).

Variabel-variabel tersebut merefleksikan dua dimensi penting strategi bisnis dalam model Porter (1985), pencarian produk baru atau unik memampukan perusahaan untuk membebankan harga premium dan efisiensi utilitas aset. Sebagai contoh, efisiensi pemanfaatan aset menunjukkan pentingnya strategi kepemimpinan biaya bagi perusahaan. Perusahaan dengan strategi kepemimpinan biaya menekankan perlunya mengeluarkan biaya serendah mungkin dalam industri. Perusahaan semacam ini perlu mencapai efisiensi operasi melalui economies of scale, pemangkasan biaya, pengetatan biaya dan pengendalian overhead, dan minimisasi biaya di bidang riset dan pengembangan, jasa, tenaga pemasar dan advertensi (Porter 1980). Hasilnya, perusahaan dengan strategi kepemimpinan biaya diharapkan memiliki rasio efisiensi pemanfaatan aset yang lebih tinggi dibanding perusahaan dengan strategi diferensiasi produk. Kapabilitas harga premium menunjukkan kemampuan perusahaan untuk membebani para pelanggannya dengan harga premium. Lynn (1994), beranggapan bahwa perusahaan yang mengadopsi strategi diferensiasi produk menawarkan produk dan jasa yang unik. Konsekuensinya, perusahaan yang mengadopsi strategi diferensiasi produk diharapkan memiliki rasio kapabilitas harga premium yang lebih tinggi dibandingkan perusahaan dengan strategi kepemimpinan biaya.

\section{Leverage keuangan}

Leverage keuangan adalah rasio total utang terhadap total nilai buku aset. Ukuran leverage keuangan untuk setiap perusahaan didasarkan pada nilai buku utang dan nilai buku aset. Teori struktur modal menyatakan bahwa leverage keuangan seharusnya diukur dengan menggunakan nilai pasar, namun sebagian penelitian empiris menggunakan nilai buku karena nilai buku lebih obyektif. Sebuah survei yang dilakukan oleh Toy et al. (1974) menunjukan bahwa manajer keuangan cenderung mengacu pada nilai buku dibanding nilai pasar ketika mendiskusikan leverage keuangan.

\section{Variabel kontrol}

Peneliti mengontrol ukuran perusahaan, kepemilikan institusional, dan pembayaran dividen. Penelitian terdahulu menyatakan bahwa ukuran perusahaan mempengaruhi struktur, kapabilitas pembuatan keputusan, dan kinerja (Bluedorn 1993; Frank dan Goyal 2003; Ramaswamy 2001). Oleh karena itu, penelitian ini memasukkan SIZE sebagai salah satu variabel kontrol untuk menguji bahwa ukuran perusahaan tidak mempengaruhi hasil. Fungsi 
logaritma total aset digunakan untuk mengendalikan pengaruh non-hipotesis ukuran perusahaan terhadap variabel dependen. Kepemilikan institusional juga mempengaruhi kinerja karena mereka mampu memonitor manajer secara efektif. Peneliti mengukur kepemilikan institusional menggunakan rasio saham yang dimiliki oleh pemegang saham institusi terhadap total saham yang beredar. Kebijakan pembayaran dividen dapat mempengaruhi kinerja perusahaan karena perusahaan yang membayar dividen tinggi dapat memiliki nilai pasar yang tinggi dan nilai buku aset yang lebih rendah dibanding perusahaan yang membayar dividen rendah.

Tabel 1. Pemilihan Sampel

Panel A: Pemilihan perusahaan

1. Jumlah perusahaan terdaftar

2. Dikurang: Perusahaan Non-Manufaktur

- Agriculture

- Mining

21

41

- Basic Industry \& Chemical

- Miscellaneous

- Consumer Goods

- Property, RE, dan BC

- Infrastructure, Utility, \& Transport

- Finance

- Trade, Services, \& Investment

3. Dikurang perusahaan yang datanya tidak lengkap

4. Jumlah perusahaan terpilih

5. Jumlah observasi (perusahaan-tahun)

Panel B: Rincian perusahaan menurut strategi kompetisi

1. Strategi kepemimpinan biaya

2. Strategi diferensiasi produk

\begin{tabular}{cc} 
Jumlah Perusahaan & Jumlah Observasi \\
104 & 520 \\
25 & 125 \\
\hline 129 & 645 \\
\hline
\end{tabular}

\section{Hasil dan Pembahasan}

Berdasarkan proses penentuan sampel di atas, penelitian ini menggunakan data perusahaan manufaktur sebanyak 129 perusahaan yang terdaftar di Bursa Efek Indonesia untuk tahun 2010 sampai dengan tahun 2014. Dengan demikian jumlah observasi yang digunakan dalam penelitian ini adalah 645 observasi (firm-years). Rincian sampel yang dipilih disajikan pada Tabel 1 .

\section{Analisis Klaster Hirarkis dan Uji t}

Analisis data diawali dengan melakukan analisis hierarchical cluster untuk membagi sampel ke dalam dua kelompok strategi bisnis, yaitu strategi kepemimpinan biaya dan strategi diferensiasi produk. Klasifikasi sampel perusahaan dilakukan dengan menggunakan variabel asset utilization efficiency dan variabel premium price capability. Analisis icicle plot, agglomeration coefficient, dan dendogram yang dihasilkan dari analisis hierarchical cluster menghasilkan dua klaster yang berbeda yang menunjukkan karakteristik ekspektasian tentang klasifikasi variabel. Tabel 1 menyajikan hasil analisis hierarchical cluster berupa dua klaster. Klaster 1 terdiri atas 104 perusahaan dan klaster 2 terdiri atas 25 perusahaan.

Setelah dilakukan analisis hierarchical cluster, peneliti melakukan uji t (t-test) dan hasilnya disajikan di Tabel 2. Hasil t-tes menunjukkan bahwa Klaster satu memiliki rasio premium price capability yang secara signifikan lebih tinggi $(t=-2.146 ; \mathrm{p}<0.005)$ namun secara signifikan memiliki rasio asset utilization efficiency yang lebih rendah dibandingkan dengan Klaster dua. Oleh karena itu, Klaster satu ditetapkan sebagai kelompok perusahaan yang menerapkan strategi diferensiasi produk dan Klaster dua sebagai kelompok perusahaan yang menerapkan strategi kepemimpinan biaya.

Tabel 2. Strategi Bisnis berdasarkan Analisis Hierarchical Cluster

\begin{tabular}{lccc}
\hline & $\begin{array}{c}\text { Cluster 1: } \\
\text { Differensiasi Produk }\end{array}$ & $\begin{array}{c}\text { Cluster 2: } \\
\text { Cost Leadership }\end{array}$ & $\begin{array}{c}\text { Hasil Uji Beda Statistis } \\
\text { (t-test) }\end{array}$ \\
\hline Premium price capability & 0.761 & 0.200 & $-2.146^{* *}$ \\
Asset utilization efficiency & 2.111 & 0.999 & $-8.913^{* * *}$ \\
\hline
\end{tabular}




\section{Statistik Deskriptif dan Bivariate}

Tabel 3 menyajikan statistik deskriptif untuk variabel dependen, variabel independen, dan variabel kontrol. Rerata (mean) untuk variabel kinerja (PFM) adalah 2.297. Dari jumlah sampel sebanyak 129 perusahaan, 81\% diantaranya adalah perusahaan yang menerapkan strategi kepemimpinan biaya, sedangkan 19\% sisanya adalah perusahaan yang menerapkan strategi diferensiasi produk. Mean untuk rasio antara jumlah utang dan jumlah asset (leverage) adalah 0.604 dan untuk ukuran perusahaan (size) adalah 3.181. Mean untuk kepemilikan institusi adalah 0.815 sedangkan mean untuk persentase pembayaran dividen (dividend payout) adalah 12.190.

Tabel 3. Statistik Deskriptif

\begin{tabular}{|c|c|c|c|c|c|}
\hline & Mean & Median & Maximum & Minimum & Std. Dev. \\
\hline PFM & 2.297 & 1.117 & 74.560 & -46.310 & 6.175 \\
\hline STR & 0.194 & 0.000 & 1.000 & 0.000 & 0.396 \\
\hline DIV & 12.190 & 0.000 & 936.970 & -450.810 & 56.188 \\
\hline $\mathrm{IO}$ & 0.815 & 0.738 & 80.000 & 0.000 & 3.136 \\
\hline LEV & 0.604 & 0.501 & 12.000 & 0.016 & 0.742 \\
\hline SIZE & 3.181 & 3.126 & 5.373 & 0.699 & 0.716 \\
\hline
\end{tabular}

Tabel 4 menyajikan korelasi antar variabel yaitu korelasi Spearman (sisi atas) dan korelasi Pearson (sisi bawah). Hasilnya menunjukkan bahwa korelasi Spearman dan Pearson secara kualitatif sama. Korelasi negatif antara LEV dan PFM konsisten dengan pendapat bahwa pendanaan utang menciptakan problem investasi yang rendah (under-investment) karena pemegang saham tidak bersedia untuk berbagai hasil investasi dengan kreditur (Myers 1977). Korelasi antar variabel ini memberikan dasar bagi pengujian pengaruh strategi terhadap hubungan antara leverage dan kinerja sekaligus pengujian hipotesis yang akan dilakukan dengan menggunakan uji regresi berganda.

Tabel 4. Analisis Bivariate

\begin{tabular}{lrrrrrrr}
\hline & \multicolumn{1}{l}{ STR } & \multicolumn{1}{c}{ DIV } & \multicolumn{1}{l}{ IO } & \multicolumn{1}{l}{ LEV } & \multicolumn{1}{l}{ PFM } & \multicolumn{1}{l}{ SIZE } & \multicolumn{2}{l}{ STR*LEV } \\
\hline STR & 1 & .035 & -.017 & .152 & .160 & -.005 & .324 \\
DIV & .035 & 1 & -.005 & -.052 & .048 & .044 & -.033 \\
IO & -.017 & -.005 & 1 & -.014 & .003 & -.015 & -.015 \\
LEV & .152 & -.052 & -.014 & 1 & -.081 & -.236 & .952 \\
PFM & .160 & .048 & .003 & -.081 & 1 & .084 & -.031 \\
SIZE & -.005 & .044 & -.015 & -.236 & .084 & 1 & -.227 \\
STR*LEV & .324 & -.033 & -.015 & .952 & -.031 & -.227 & 1 \\
\hline
\end{tabular}

**. Korelasi signifikan pada level 0.01 (2-tailed).

*. Korelasi signifikan pada level 0.05 (2-tailed).

\section{Uji Hipotesis}

Uji hipotesis dilakukan dengan menggunakan metode ordinary least square (OLS). Sebelum dilakukan pengujian, peneliti melakukan uji asumsi klasik terlebih dahulu. Dari hasil uji tersebut terbukti bahwa data terdistribusi secara normal dan tidak ada masalah dengan multikolinieritas, heteroskedastisitas, dan otokorelasi serta tidak terdapat outlier dalam data. Hasil analisis regresi disajikan pada Tabel 5. Model 1 (dengan interaksi) menunjukkan efek interaksi strategi bisnis terhadap hubungan antara leverage dan kinerja. Model 2 (tanpa interaksi) menunjukkan pengaruh langsung variabel independen yaitu leverage dan strategi bisnis terhadap variabel dependen yaitu kinerja. Meskipun variabel yang diteliti (variable of interest) pada kedua model tersebut secara statistis signifikan, namun model 1 memberikan gambaran yang lebih komprehensif tentang hubungan antara leverage dan kinerja dibanding model 2 (Cohen et al. 2003) 
Tabel 5. Analisis Regresi

\begin{tabular}{|c|c|c|c|c|c|c|c|}
\hline \multicolumn{4}{|c|}{ 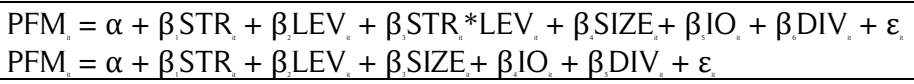 } & $\begin{array}{l}(1) \\
(2)\end{array}$ & & & \\
\hline \multirow{2}{*}{ Variabel } & \multicolumn{3}{|c|}{$\begin{array}{l}\text { SIZE }+\beta I O+\beta \text { DIV }+\varepsilon \\
\text { Model } 1 \text { - Dengan Interaksi }\end{array}$} & \multicolumn{4}{|c|}{ Model 2 - Tanpa Interaksi } \\
\hline & Coefficien & & t-statistic & & Coefficien & & t-statistic \\
\hline Intersep & 0.649 & & 0.495 & & 0.234 & & 0.194 \\
\hline STR & 1.506 & $* *$ & 2.231 & & 2.227 & $* * *$ & 3.470 \\
\hline DIV & 0.006 & $*$ & 1.702 & & 0.006 & $*$ & 1.704 \\
\hline $\mathrm{IO}$ & 0.017 & & 1.085 & & 0.018 & & 1.073 \\
\hline LEV & -1.513 & $* * *$ & -10.169 & & -0.667 & $* * *$ & -4.244 \\
\hline SIZE & 0.614 & $*$ & 1.723 & & 0.596 & $*$ & 1.668 \\
\hline STR*LEV & 1.142 & $* * *$ & 6.717 & & & & \\
\hline Adj. $R^{2}$ & 0.042 & & & & 0.038 & & \\
\hline F-statistic & 5.713 & $* * *$ & & & 6.191 & $* * *$ & \\
\hline
\end{tabular}

***, $* *, *$ menunjukkan bahwa koefisien variabel signifikan pada level $0.01,0.05$, dan 0.1

Hasil di Tabel 5, baik untuk model 1 maupun model 2 menunjukkan bahwa koefisien LEV bernilai negatif dan signifikan pada level $1 \%(\mathrm{p}<0.001)$. Hasil ini konsisten dengan penelitian yang dilakukan oleh Jermias (2008), Frank dan Goyal (2003), dan Balakrishnan dan Fox (1993). Hipotesis 1 memprediksi bahwa hubungan antara leverage dan kinerja lebih negatif pada perusahaan yang menerapkan strategi diferensiasi produk dibandingkan pada perusahaan yang menerapkan strategi kepemimpinan biaya. Hipotesis 1 menekankan pada peningkatan pengaruh STR terhadap hubungan antara leverage dan kinerja. Hasil pengujian hipotesis 1 ditunjukkan oleh koefisien interaksi STR*LEV pada kolom Model 1 pada Tabel 5, yaitu bernilai positif dan secara statistis signifikan pada level $1 \%(\beta=1.142 ; p<0.001)$. Karena STR bernilai 1 untuk cost leaders dan bernilai 0 untuk product differentiators, maka koefisien LEV menggambarkan hubungan linier antara leverage dan kinerja perusahaan. Untuk cost leaders, hubungan ini dicerminkan jumlah koefisien LEV dan STR*LEV, sedangkan untuk product differentiators, hubungan ini direpresentasikan hanya oleh koefisien LEV. Oleh karena itu, hasil analisis menunjukkan bahwa hubungan antara leverage dan kinerja lebih negatif untuk perusahaan yang menerapkan strategi diferensiasi produk dibandingkan perusahaan yang mengadopsi strategi kepemimpinan biaya. Perubahan strategi dari cost leader (bernilai 0) ke strategi product differentiators (bernilai 1) akan mengubah slope dari 1.513 menjadi $-0.371(-1.513+1.142)$. Hasil ini konsisten dengan $\mathrm{H} 1$ yang menyatakan bahwa strat pengaruh leverage terhadap kinerja menjadi lebih negatif untuk perusahaan yang mengadopsi strategi product differentiation dibanding perusahaan yang mengadopsi strategi cost leadership.

Hasil ini juga konsisten dengan pandangan bahwa pendanaan utang dan atau kontrak utang tidak hanya menawarkan manfaat bagi perusahaan pengadopsi kepemimpinan biaya berupa keuntungan pajak, namun juga manfaat berupa efisiensi karena adanya pembatasan yang dilakukan oleh kreditur (Jensen 1986; O'Brien 2003; Simerly dan Li 2000). Sebaliknya, biaya utang lebih tinggi pada perusahaan pengadopsi diferensiasi produk karena pembatasan yang dilakukan oleh kreditur membatasi kemampuan manajer untuk melakukan tindakan yang kreatif dan inovatif untuk keberhasilan perusahaan (Jermias 2008). Pengaruh interaksi trategi dan leverage kinerja tidak konsisten dengan proposisi Modigliani dan Miller (1958), yang menyatakan bahwa leverage keuangan independen terhadap kinerja perusahaan. Meskipun demikian temuan ini mengindikasikan bahwa leverage keuangan mempengaruhi kinerja perusahaan meskipun pengaruh tersebut dipengaruhi oleh strategi bisnis perusahaan. Temuan ini membantu menjelaskan inkonsistensi dan kontradiksi temuan penelitian terdahulu tentang pengaruh utang terhadap kinerja yang bervariasi di berbagai konteks. Temuan ini konsisten dengan hasil riset yang dilakukan oleh Jermias (2008) yang melakukan penelitian pada perusahaan manufaktur di Amerika Serikat.

Untuk variabel kontrol, hasil analisis menunjukkan bahwa ukuran perusahaan (SIZE) berpengaruh positif dan signifikan $(\beta=0.614 ; p<0.01)$ terhadap kinerja. Temuan ini tidak konsisten dengan hasil riset terdahulu yang dilakukan oleh Robinson dan McDougall (2001). Kepemilikan institusional (IO) tidak berpengaruh ( $\beta=0.017$; $\mathrm{p}>0.01)$ terhadap kinerja. Hasil ini mengindikasikan bahwa monitoring yang dilakukan oleh pemegang saham institusi tidak efektif dan tidak berdampak positif. Sedangkan dividen berpengaruh positif signifikan $(\beta=0.006$; $\mathrm{p}<0.1$ ). Hal ini mengandung arti bahwa semakin besar dividen yang dibayarkan maka kinerja keuangan (nilai pasar perusahaan) semakin besar pula.

\section{Analisis Tambahan}

Analisis tambahan dilakukan dengan tujuan untuk mengetahui pengaruh setiap jenis strategi terhadap hubungan langsung antara leverage dan kinerja perusahaan. Analisis regresi dilakukan dengan menggunakan model persamaan 3 dan 4 berikut ini. 


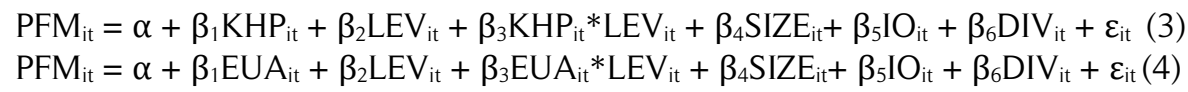

KHP adalah kapabilitas harga premium dan merupakan proksi strategi diferensiasi produk, sedangkan EUA adalah efisiensi utilitas asset dan merupakan proksi strategi cost leadership. Hasil analisis disajikan di Tabel 6. Hasil di tabel 6 menunjukkan bahwa baik strategi diferensiasi produk maupun cost leadership yang ditunjukkan oleh koefisiensi regresi variabel KHP*LEV $(\beta=-1.284 ; p>0.01)$ dan EUA*LEV $(\beta=-0.390 ; p>0.01)$ mempengaruhi hubungan antara LEV dan PFM. Meskipun variabel interaksi tersebut berpengaruh secara negatif signifikan, namun jika dilihat besarnya koefisien nampak bahwa koefisien KHP*LEV (untuk perusahaan yang menerapkan strategi product differentiation) yaitu -1.284 lebih negatif dibandingkan koefisien regresi EUA*LEV (untuk perusahaan yang menerapkan strategi cost leadership) yaitu sebesar -0.390. Kondisi ini konsisten dengan hasil analisis regresi pada Tabel 5 yang mengkofirmasi hipotesis.

Tabel 6. Hasil Regresi Per Individu Strategi Bisnis

\begin{tabular}{|c|c|c|c|c|c|c|}
\hline \multicolumn{7}{|c|}{$\begin{array}{l}\mathrm{PFM}_{\text {it }}=\alpha+\beta_{1} \mathrm{KHP}_{\mathrm{it}}+\beta_{2} \mathrm{LEV}_{\mathrm{it}}+\beta_{3} \mathrm{KHP}_{\mathrm{it}} * \mathrm{LEV}_{\mathrm{it}}+\beta_{4} \mathrm{SIZE}_{\mathrm{it}}+\beta_{5} \mathrm{IO}_{\mathrm{it}}+\beta_{6} \mathrm{DIV}_{\mathrm{it}}+\varepsilon_{\text {it }}(3) \\
\mathrm{PFM}_{\mathrm{it}}=\alpha+\beta_{1} \mathrm{EUA}_{\mathrm{it}}+\beta_{2} \mathrm{LEV}_{\text {it }}+\beta_{3} \mathrm{EUA}_{\mathrm{it}} * \mathrm{LEV}_{\mathrm{it}}+\beta_{4} \mathrm{SIZE}_{\mathrm{it}}+\beta_{5} \mathrm{IO}_{\mathrm{it}}+\beta_{6} \mathrm{DIV}_{\mathrm{it}}+\varepsilon_{\mathrm{it}}(4)\end{array}$} \\
\hline \multirow{2}{*}{ Variabel } & \multicolumn{3}{|c|}{ Model 3} & \multicolumn{3}{|c|}{ Model 4} \\
\hline & Coefficie & & t-statistic & Coefficien & & t-statistic \\
\hline Intersep & -0.659 & $*$ & -1.803 & -1.071 & $* * *$ & -1.803 \\
\hline KHP & 4.092 & $* * *$ & 7.768 & & & \\
\hline EUA & & & & 0.953 & $* * *$ & 7.768 \\
\hline DIV & 0.002 & $* *$ & 1.976 & 0.002 & $*$ & 1.976 \\
\hline IO & 0.014 & & 1.438 & -0.001 & & 1.438 \\
\hline LEV & -0.128 & $* *$ & -2.310 & -0.188 & $* * *$ & -2.310 \\
\hline SIZE & 0.567 & $* * *$ & 6.381 & 0.662 & $* * *$ & 6.381 \\
\hline KHP*LEV & -1.284 & $* * *$ & -8.041 & & & \\
\hline EUA*LEV & & & & -0.390 & $* * *$ & -8.041 \\
\hline Adj. $R^{2}$ & 0.485 & & & 0.279 & & \\
\hline F-statistic & 87.809 & $* * *$ & & 42.464 & $* * *$ & \\
\hline
\end{tabular}

$* * *, * *, *$ menunjukkan bahwa koefisien variabel signifikan pada level 0.01, 0.05, dan 0.1

\section{Simpulan}

Penelitian ini menginvestigasi pengaruh strategi perusahaan terhadap hubungan antara leverage keuangan dan kinerja perusahaan. Hasil penelitian menunjukan bahwa hubungan antara leverage dan kinerja lebih negatif untuk perusahaan yang menerapkan strategi diferensiasi produk dibandingkan perusahaan yang mengadopsi strategi kepemimpinan biaya. Hasil penelitian ini konsisten dengan penelitian sejenis yang dilakukan di Amerika Serikat dan sekaligus memberikan penjelasan mengapa penelitian yang menginvestigasi pengaruh langsung leverage keuangan terhadap kinerja cenderung tidak konsisten (mixed) dan bahkan saling bertentangan.

Meskipun demikian, penelitian ini memiliki beberapa keterbatasan. Pertama, penelitian ini tidak mempertimbangkan variabel lain yang mungkin berpengaruh terhadap kinerja, misalnya karakteristik manajerial, jenis pengendalian, dan jenis sistem akuntansi manajemen yang digunakan oleh perusahaan. Oleh karena itu penelitian lanjutan perlu dilakukan dengan melibatkan faktor-faktor tersebut. Kedua, penelitian yang dilakukan oleh Parthiban et al. (2008) mengungkapkan bahwa jenis utang (utang bank dan utang obligasi) mempengaruhi hubungan antara strategi kompetisi dan kinerja. Oleh karena itu, penelitian lanjutan dapat dilakukan dengan mempertimbangkan perbedaan jenis utang untuk membuktikan apakah hasilnya konsisten dengan hasil penelitian ini. Ketiga, dalam penelitian ini digunakan data perusahaan manufaktur. Penelitian lanjutan dapat dilakukan untuk menguji kelompok industri atau sektor lain.

\section{Daftar Pustaka}

Ahmad, N., A. Salman, dan A. F. Shamsi. 2015. Impact of financial leverage on firms' profitability: an investigation from cement sector of Pakistan. Research Journal of Finance and Accounting 6 (7): 75-80.

Akhtar, S., B. Javed, A. Maryan, dan H. Sadia. 2012. Relationship between financial leverage and financial performance: evidence from fuel \& energy sector of Pakistan. European Journal of Business and Management 4 (11): 8-17. 
Ali, K. A. 2014. The impact of financial leverage on firm performance: the case of non financial firms in Kenya. Reseach Project. University of Nairobi.

Baginski, S., dan J. Wahlen. 2003. Residual income risk, intrinsic values, and share price. The Accounting Review 78 (1): 327-351.

Balakrishnan, S., dan I. Fox. 1993. Asset specificity, firm heterogeneity and financial leverage. Strategic Management Journal 14 (1): 3-16.

Barton, S. L., dan P. J. Gordon. 1988. Corporate strategy and financial leverage. Strategic Management Journal 9 (6): 623-632.

Berger, A. N., dan E. B. Patti. 2006. Capital structure and firm performance: a new approach to testing agency theory and an application to the banking industry. Journal of Banking and Finance 30 (4): 1065-1102.

Biggadike, R. 1979. The risky business of diversification. Harvard Business Review 57 (3): 103-111.

Bluedorn, A. C. 1993. Pilgrim's progress: trends and convergence in research on organizational size and environments. Journal of Management 19 (2): 163-191.

Chenhall, R. H., dan K. Langfield-Smith. 1998. The relationship between strategic priorities, management techniques, and management accounting: an empirical investigation using a system approach. Accounting, Organizations and Society 23 (3): 243-264.

Cohen, J., P. Cohen, S. G. West, L. S. Aiken. 2003. Applied Multiple Regression/Correlation Analysis for the Behavioural Sciences. London: Lawrence Erlbaum Associates.

Dess, G. G., dan P. S. Davis. 1984. Porter's 1980 generic strategies as determinant of strategic group membership and organizational performance. Academy of Management Journal 27 (3): 467-488.

Enekwe, C. I., C. I. Agu, dan K. N. Ezeido. 2014. The effect of financial leverage on financial performance: evidence of quoted pharmaceutical companies in Nigeria. IOSR Journal of Economics and Finance 5 (3): $17-25$.

Evgeny, I. 2015. The impact of financial leverage on firm performance: evidence from Russia. Journal of Corporate Finance Research 2 (34): 24-36.

Frank, M. Z., dan V. K. Goyal. 2003. Testing the pecking order theory of capital structure. Journal of Financial Economics 67: 217-248.

Ghosh, C., R. Nag, dan C. F. Sirmans. 2000. The pricing of seasoned equity offerings: evidence from REITs. Real Estate Economics 28 (3): 363-384.

Ginsberg, A., dan N. Venkatraman. 1985. Contingency perspectives of organizational strategy: a critical review of the empirical research. Academy of Management Review 10 (3): 421-434.

Gleason, K. C., L. K. Mathur, dan I. Mathur. 2000. The interrelationship between culture, capital structure, and performance: evidence from European retailers. Journal of Business Research 50 (2): 185-191.

Govindarajan, V. 1988. A contingency approach to strategy implementation at the business unit level: integrating administrative mechanisms with strategy. Academy of Management Journal 31 (4): 828-853.

Govindarajan, V., dan J. Fisher. 1990. Strategy, control systems, and resource sharing: effects on business unit performance. Academy of Management Journal 33 (2): 259-285.

Hambrick, D. C. 1983. High profit strategies in mature capital goods industries: a contingency approach. Academy of Management Journal 26 (4): 687-707.

Harris, F. H. D. 1994. Asset specificity, capital intensity, and capital structure: an empirical test. Managerial and Decision Economics 15 (6): 563-577.

Harris, M., dan A. Raviv. 1991. The theory of capital structure. Journal of Finance 46 (1): 297-355.

Javed, Z. H., H. Rao, B. Akram, dan M. F. Nazir. 2015. Effect of financial leverage on performance of the firms: empirical evidence from Pakistan. SPOUDAI Journal of Economics and Business 65 (1-2): 87-95. 
Jensen, M. C. 1986. Agency costs of free cash flow, corporate finance, and takeovers. AEA Papers and Proceedings, May. . 1989. Eclipse of the public corporation. Harvard Business Review September-October.

Jensen, M. C., dan W. H. Meckling. 1976. Theory of the firm, managerial behaviour, agency costs and ownership structure. Journal of Financial Economics 3 (4): 305-360.

Jermias, J. 2008. The relative influence of competitive intensity and business strategy on the relationship between financial leverage and performance. The British Accounting Review 40: 71-86.

Jordan, J., J. Lowe, dan P. Taylor. 1998. Strategy and financial policy in UK small firms. Journal of Business Finance and Accounting 25 (1-2): 1-27.

Lubatkin, M., dan S. Chatterjee. 1994. Extending modern portfolio theory into the domain of corporate diversification: does it apply? Academy of Management Journal 37 (1): 109-136.

Lynn, T. A. 1994. Learning from competition. Journal of Accountancy 177 (2): 43-46.

Megginson, W. L. 1997. Corporate Finance Theory. Addison Wesley Educational Publishers.

Merchant, K. A., dan W. A. Van der Stede. 2007. Management Control Systems: Performance Measurement, Evaluation and Incentives. New York: Prentice-Hall.

Miller, D. 1987. The structural and environmental correlates of business strategy. Strategic Management Journal 8 (1): 55-76.

Modigliani, F., dan M. H. Miller. 1958. The cost of capital, corporate finance, and the theory of investment. The American Economic Review 48 (3): 261-297.

Moores, K., dan S. Yuen. 2001. Management accounting systems and organizational configuration: a life-cycle perspective. Accounting, Organizations and Society 26 (4-5): 351-389.

Mule, K. M., dan M. S. Mukras. 2015. Financial leverage and performance of listed firms in a frontier market: panel evidence from Kenya. European Scientific Journal 7 (11): 534-550.

Myers, S. 1977. Determinants of corporate borrowings. Journal of Financial Economics 5 (1): 147-175.

O'Brien, J. P. 2003. The financial leverage implications of pursuing a strategy of innovation. Strategic Management Journal 24 (5): 415-431.

Parthiban, D., J. P. O'Brien, dan T. Yoshikawa. 2008. The implications of debt heterogeneity for R\&D investment and firm performance. The Academy of Management Journal 51 (1): 165-181.

Porter, M. E. 1980. Competitive Strategy. New York: Free Press. . 1985. Competitive Advantage. New York: Free Press. 1996. What is strategy? Harvard Business Review 74 (6): 61-78.

Rajkumar, P. 2014. Impact of financial leverage on financial performance: special reference to john keells holdings plc in Sri Lanka. Scientific Research Journal 2 (2): 15-20.

Ramaswamy, K. 2001. Organizational ownership, competitive intensity, and firm performance: an empirical study of the Indian manufacturing sector. Strategic Management Journal 22 (10): 989-998.

Robinson, K. C. dan P. P. McDougall. 2001. Entry barriers and new venture performance: a comparison of universal and contingency approaches. Strategic Management Journal 22 (6-7): 659-685.

Rahimi, J. 2016. The effect of business strategies on the relationship between leverage relative and financial performance of listed companies in Tehran Stock Exchange. Information and Knowledge Management 6 (2): $17-26$.

Shaheen, W. 2014. Impact of leverage on financial performance of the organization. Available at SSRN: https://ssrn.com/abstract=2471545

Simerly, R. L., dan M. Li. 2000. Environmental dynamism, financial leverage and performance: a theoretical integration and an empirical test. Strategic Management Journal 21 (1): 31-49. 
Simons, R. 2000. Performance measurement and control systems for implementing strategy: text and cases. New Jersey: Prentice-Hall.

Singh, P., dan N. C. Agarwal. 2002. The effects of firm strategy on the level and structure of executive compensation. Canadian Journal of Administrative Sciences 19 (1): 42-56.

Spence, M. 1985. Capital structure and the corporation's product market environment. In: B. Friedman (Ed.) Corporate Capital Structure in the United States. Chicago: University of Chicago Press.

Tahir, S. H., R. Rehman, dan N. U. Rehman. 2014. Corporate governance and financial leverage impact on the value of firms, evidence from textile sector Pakistani listed companies. Business Journal of Economics \& Business Studies 3 (6): 25-33

Toy, N., A. Stonehill, L. Remmers, dan T. Beekhuisen. 1974. Comparative international study of growth, profitability, and risk as determinants of corporate debt ratios in the manufacturing sector. Journal of Financial and Quantitative Analysis 9 (5): 875-886.

Weill, L. 2003. Leverage and corporate performance: a frontier efficiency analysis on European countries. EFMA 2003 Helsinki Meetings. Tersedia di SSRN: https://ssrn.com/abstract=300640 atau http://dx.doi.org/10.2139/ssrn.300640. 